\title{
Faktor-Faktor yang Memengaruhi Hasil Belajar Peserta Pelatihan Berbasis Kompetensi di UPT BLK Singosari Malang
}

\author{
Annisa Wahyu Rosena, Zulkarnain, Edi Widianto \\ Universitas Negeri Malang, Jl. Semarang No. 5 Malang, Jawa Timur, Indonesia \\ *Penulis korespondensi, Surel: annisa.wahyu.1701416@students.um.ac.id
}

Paper received: 28-9-2021; revised: 12-10-2021; accepted: 19-10-2021

\begin{abstract}
Abstrak
Penelitian mengenai faktor yang memengaruhi hasil belajar dilaksanakan di UPT BLK Singosari Malang untuk mengetahui gambaran faktor serta pengaruhnya terhadap hasil belajar peserta pelatihan. Pendekatan penelitian yang digunakan adalah kuantitatif yang menekankan pada penggunaan angka dan analisis statistik. Responden terdiri dari 69 peserta pelatihan pada program pemerintah tahun 2021 dengan instrumen penelitian berupa angket dan catatan hasil belajar sebagai penghimpun data. Pengujian hipotesis dilakukan dengan teknik analisis regresi linier berganda. Hasil penelitian secara parsial menunjukkan bahwa faktor kesehatan, motivasi, keluarga dan masyarakat berpengaruh signifikan terhadap hasil belajar peserta pelatihan, sedangkan faktor intelegensi, bakat, minat dan lembaga tidak berpengaruh signifikan. Sementara itu, hasil uji simultan menunjukkan faktor-faktor tersebut berpengaruh signifikan terhadap hasil belajar peserta pelatihan dengan besaran kontribusi 36,7 persen. Hasil belajar peserta pelatihan memperlihatkan nilai yang bervariasi dengan nilai terendah 81,04 dan tertinggi 89,09 dengan mayoritas peserta memperoleh predikat baik sekali.
\end{abstract}

Kata kunci: hasil belajar; pelatihan; balai latihan kerja

\section{Pendahuluan}

Pada masa persaingan kerja yang semakin ketat, pengembangan sumber daya manusia mutlak diperlukan sehingga dapat masuk dan bersaing pada pasar kerja global. Pengembangan SDM dilakukan sebagai upaya untuk menciptakan tenaga kerja yang memiliki keahlian dan kompetensi sesuai dengan bidangnya. Salah satu upaya yang dapat dilakukan untuk mengembangkan SDM adalah pelatihan berbasis kompetensi. Pelatihan berbasis kompetensi merupakan proses pelatihan yang diselenggarakan untuk mengembangkan keahlian tertentu guna mencapai hasil kerja yang telah ditetapkan (Hani, 2020). Kegiatan pelatihan dilakukan dalam waktu relatif singkat dimana peserta didik mempelajari bidang keahlian tertentu secara terbatas. Prosesnya dibagi dalam tiga tahapan, yaitu perencanaan, pelaksanaan serta evaluasi dan tindak lanjut (Widianto, 2018)

Penyelenggaraan pelatihan berbasis kompetensi akan membimbing peserta pada pengembangan keahlian dalam melakukan tugas dan tanggungjawab sesuai dengan bidang pekerjaan yang dilakukan. Peserta didik akan dilatih sesuai dengan bidang kejuruan dan diajarkan berbagai kemampuan yang dibutuhkan untuk menjalankan suatu pekerjaan serta berguna untuk meningkatkan efektivitas dan produktivitas ketika bekerja. Selain itu, pelatihan ini juga memberi bekal dalam hal budaya kerja maupun wirausaha sehingga sikap peserta didik juga dibangun. Seseorang dikatakan memiliki kompetensi apabila ia mampu mengerjakan pekerjaan dengan cara yang rasional. Secara global, pelatihan berbasis kompetensi dimaksudkan untuk meningkatkan kemampuan sehingga dapat memperluas pengetahuan, menambah keterampilan dan mengembangkan sikap. 
Pada dasarnya, pelatihan diberikan sebagai upaya untuk mengembangkan dan memelihara kesiapan peserta didik dalam menjalankan pekerjaan. Tujuan pelatihan adalah mengenalkan dan merubah tingkah laku sehingga tercipta tingkah laku baru. Kegiatan pelatihan tidak boleh dilakukan sembarangan. Untuk mengetahui jenis dan cara pelatihan yang tepat diperlukan analisis kebutuhan pelatihan guna mengidentifikasi pelatihan yang sesuai. Ada beberapa syarat yang harus terpenuhi agar suatu kegiatan dapat disebut pelatihan, yaitu membantu peserta didik meningkatkan kemampuan, menciptakan perubahan sikap dan tingkah laku, serta pelatihan harus berkaitan dengan bidang pekerjaan tertentu (Lodjo, 2013). Apabila syarat tersebut belum terpenuhi, maka suatu kegiatan belum bisa dikatakan sebagai pelatihan. Pada kegiatan pelatihan peserta didik akan mendapatkan serangkaian ilmu baru yang berguna sebagai landasan dalam mengembangkan kemampuannya. Pelatihan juga memungkinkan peserta didik untuk memunculkan potensi mereka.

Sebagai bagian dari pendidikan, pelatihan mengandung serangkaian kegiatan belajar dan mengutamakan praktek daripada teori. Pelaksanaan kegiatan belajar adalah inti dari kegiatan pelatihan dan berperan sebagai sarana untuk mencapai tujuan, yaitu adanya perubahan pada peserta didik yang diperlihatkan melalui hasil belajar. Apabila dalam suatu kegiatan belajar seseorang tidak menunjukkan adanya perubahan tingkah laku maka orang tersebut bisa dikatakan belum belajar atau dengan kata lain gagal dalam belajar. Hasil belajar menunjukkan penguasaan peserta didik mengenai bahan ajar yang diberikan kepada mereka yang biasanya ditunjukkan dengan angka atau huruf dan berfungsi sebagai alat pengukur keberhasilan belajar.

Hasil belajar peserta pelatihan adalah bentuk peningkatan terhadap kompetensi yang ditunjukkan melalui berbagai aspek baik kognitif, afektif dan psikomotorik (Saputri, Purwito, \& Widianto, 2019). Hasil belajar setiap peserta pelatihan tidak sama. Hal ini dikarenakan belajar adalah sebuah proses dengan bermacam-macam faktor yang memengaruhi. Faktor tersebut dapat diklasifikasikan menjadi dua, yaitu faktor dari dalam diri atau internal dan dari luar diri atau eksternal peserta pelatihan yang sedang belajar. Baik faktor internal maupun eksternal, keduanya turut berkontribusi pada pencapaian hasil belajar.

Faktor internal merupakan kondisi jasmani rohani peserta didik. Menurut Syah (2011) faktor internal dibagi menjadi dua aspek, yaitu fisiologis dan psikologis. Aspek fisiologis adalah keadaan jasmani seseorang yang diketahui melalui kondisi kesehatan, sedangkan aspek psikologis adalah keadaan rohaniah seseorang terdiri atas inteligensi, bakat, minat dan motivasi. Sementara itu, faktor eksternal merupakan keadaan di lingkungan sekitar peserta didik. Slameto (2013) mengungkapkan faktor eksternal dibagi menjadi tiga, yaitu keluarga, sekolah dan masyarakat.

Kesehatan mengambil peran penting dalam menentukan kuantitas dan kualitas perilaku individu. Sehat adalah suatu kondisi yang menyatakan tubuh dalam kondisi baik dan terbebas dari penyakit. Keadaan tubuh yang sehat akan berdampak positif pada belajar, sebaliknya tubuh yang sakit dapat menghambat terwujudnya hasil belajar yang optimal.

Inteligensi atau tingkat kecerdasan adalah kapasitas individu untuk menerima berbagai macam keahlian. Setiap orang memiliki intelegensi yang berbeda, sebab kemampuan seseorang dalam menyelesaikan persoalan tidak sama. Peserta pelatihan dengan intelegensi tinggi akan lebih berhasil daripada peserta pelatihan dengan intelegensi rendah. Namun, inteligensi hanyalah salah satu faktor penentu keberhasilan belajar. Peserta pelatihan dengan 
inteligensi normal dapat memperoleh hasil yang baik apabila mengupayakan belajar dengan rajin dan faktor lain yang memengaruhi belajarnya cenderung ke arah positif.

Bakat adalah kemampuan individu dalam melakukan suatu aktivitas. Peserta pelatihan yang memiliki bakat pada suatu bidang keahlian akan lebih mudah menerima materi terkait bidang tersebut dibandingkan dengan peserta pelatihan lain. Mengetahui bakat penting dilakukan sehingga dapat mengarahkan pada pelatihan yang sesuai. Pemaksaan kehendak terhadap peserta dan ketidaksesuaian antara jurusan yang dipilih dengan bakat dapat berpengaruh terhadap pencapaian hasil belajar.

Minat adalah kecenderungan untuk memberi perhatian terhadap suatu hal secara terus menerus. Individu yang menaruh minat terhadap hal tertentu akan merasa senang dan memperoleh kepuasan dari hal tersebut. Peserta dengan minat besar pada kegiatan pelatihan yang diikuti akan memfokuskan perhatian lebih besar dibandingkan dengan peserta yang lain. Selanjutnya, perhatian itulah yang membuat peserta pelatihan lebih tergugah untuk belajar dan pada akhirnya mencapai hasil yang diharapkan.

Motivasi adalah dorongan untuk bertindak secara terarah. Motivasi berkaitan dengan usaha dalam mencapai tujuan dan komponen penting dalam aktivitas karena berpengaruh pada perilaku. Peserta pelatihan yang memiliki suatu motivasi tertentu akan berusaha belajar sebaik mungkin sehingga tujuannya tercapai. Hal ini tentu menjadikan hasil belajar menjadi lebih baik daripada peserta yang kurang atau tidak memiliki motivasi. Peserta pelatihan akan mendapat hasil yang maksimal apabila ada motivasi yang mendorongnya.

Keluarga tempat pendidikan utama yang berpengaruh pada keberhasilan anak. Pendidikan di keluarga menjadi penting karena anak melakukan interaksi pertama dan membentuk kepribadian dalam ruang lingkup keluarga. Peserta pelatihan dengan keluarga yang mendukung aktivitas belajar akan memperoleh hasil lebih baik daripada peserta yang tinggal dalam keluarga kurang mendukung.

Pada dunia pendidikan nonformal, faktor sekolah biasa juga disebut sebagai faktor lembaga, yaitu tempat peserta didik mengikuti pelatihan. Faktor lembaga yang dapat berpengaruh terhadap hasil belajar adalah fasilitas pelatihan serta lingkungan sosial belajar yang terdiri atas instruktur dan teman satu kelas. Segenap komponen dalam lembaga yang dapat menunjang pelaksanaan pelatihan harus dikelola sebaik mungkin agar membuahkan hasil yang baik.

Masyarakat adalah orang disekitar tempat tinggal. Masyarakat turut memberi pengaruh terhadap aktivitas belajar, sebab individu cenderung akan menyesuaikan diri dan berperilaku sama dengan orang-orang di sekitarnya. Peserta pelatihan yang tinggal dalam masyarakat kurang berpendidikan dan memiliki kebiasaan buruk akan memperoleh dampak negatif, sebaliknya masyarakat yang dipenuhi oleh orang-orang baik dan terpelajar akan menjadikan peserta terpengaruh hal positif.

Kegiatan pelatihan diselenggarakan oleh lembaga-lembaga penyedia pelatihan, baik lembaga pemerintah maupun badan-badan swasta dan organisasi kemasyarakatan lainnya. Ketiga kelompok tersebut menyelenggarakan pelatihan sesuai dengan bidangnya. Salah satu lembaga pemerintah penyedia pelatihan adalah Balai Latihan Kerja atau disingkat BLK. BLK berfungsi sebagai wadah tempat pelaksanaan pelatihan untuk pencari kerja maupun ahli 
profesi yang selanjutnya disebut pelatihan berbasis kompetensi (Ilyas, Farid, \& Akbar, 2017). Pelatihan dilakukan guna merubah tingkah laku peserta didik yang mengikutinya, yaitu mampu menyelesaikan pekerjaan dengan optimal sehingga dapat berkontribusi pada tempat bekerja. Kegiatan pelatihan dapat dikatakan berhasil apabila memberi manfaat untuk peserta didik, lembaga penyelenggara dan dunia kerja (Septyana, 2013).

Berdasarkan uraian di atas, peneliti bermaksud meneliti lebih dalam mengenai faktor yang memengaruhi hasil belajar dan membuat judul penelitian "Faktor-Faktor yang Memengaruhi Hasil Belajar Peserta Pelatihan di UPT BLK Singosari Malang”. Penelitian ini dirancang untuk memberikan deskripsi tentang faktor apa sajakah yang berpengaruh pada hasil belajar, mencakup internal dan eksternal serta pengaruhnya terhadap hasil belajar peserta pelatihan.

\section{Metode}

Penelitian ini dimaksudkan untuk memberikan deskripsi mengenai faktor yang memengaruhi hasil belajar, baik dari aspek internal maupun eksternal serta pengaruhnya terhadap hasil belajar peserta pelatihan. Pendekatan penelitian yang dipakai adalah kuantitatif, yaitu menekankan penggunaan data-data numerik dengan analisis berupa statistik. Adapun variabel penelitian terdiri dari variabel bebas (X) yakni faktor-faktor yang memengaruhi hasil belajar meliputi kesehatan $\left(\mathrm{X}_{1}\right)$, inteligensi $\left(\mathrm{X}_{2}\right)$, bakat $\left(\mathrm{X}_{3}\right)$, minat $\left(\mathrm{X}_{4}\right)$, motivasi $\left(\mathrm{X}_{5}\right)$, keluarga $\left(\mathrm{X}_{6}\right)$, lembaga $\left(\mathrm{X}_{7}\right)$ dan masyarakat $\left(\mathrm{X}_{8}\right)$ serta variabel terikat yakni hasil belajar peserta pelatihan (Y).

Lokasi penelitian adalah UPT BLK Singosari Malang yang beralamat di Jl. Raya Singosari, Kabupaten Malang, Jawa timur. BLK ini merupakan lembaga pemerintah penyelenggara pelatihan yang berfokus pada pelatihan berbasis kompetensi khususnya bidang industri. Penelitian dilaksanakan pada bulan April sampai dengan Juni 2021. Sehubungan dengan adanya pandemi Covid penelitian dilakukan dengan memperhatikan protokol kesehatan yang ada.

Populasi penelitian ini adalah peserta pelatihan di UPT BLK Singosari Malang sebanyak 87 orang. Peserta pelatihan berasal dari 6 kejuruan yang berbeda yakni Junior Administrative Assistant, Menjahit Pakaian, Pemeliharaan Kendaraan Ringan, Perakitan Komputer, Pengoperasian Mesin CNC, dan Teknisi AC Split. Pengambilan sampel dilakukan menggunakan teknik Probability Sampling, yaitu setiap peserta memperoleh peluang yang sama untuk menjadi sampel. Karakteristik peserta pelatihan dianggap homogen, namun jumlah peserta di setiap jurusan berbeda. Selanjutnya, dilakukan penarikan sampel secara proporsional dengan teknik Proportional Random Sampling. Pengambilan sampel pada masing-masing jurusan pelatihan ditentukan sebanding dengan jumlah peserta dari setiap kejuruan. Maka diperoleh sampel sejumlah 69 orang peserta pelatihan di UPT BLK Singosari Malang.

Data penelitian berupa angka dan dikumpulkan menggunakan angket (data primer) dan dokumentasi (data sekunder). Angket dipakai sebagai instrumen penelitian untuk menghimpun data mengenai faktor-faktor yang memengaruhi hasil belajar dari responden secara langsung. Angket disusun dalam bentuk butir-butir pernyataan dan menggunakan skala Likert sebagai alternatif jawaban meliputi sangat tidak setuju, tidak setuju, ragu-ragu, setuju dan sangat setuju. Nilai skor terendah adalah 1 dan tertinggi 5. Sementara itu, dokumentasi dipakai untuk menghimpun data mengenai hasil belajar peserta pelatihan melalui dokumen terkait milik UPT BLK Singosari Malang. 
Angket perlu diuji kualitasnya untuk mengetahui apakah instrumen penelitian yang digunakan sudah baik, dalam arti valid dan reliabel sebagai alat pengumpul data. Uji validitas menggunakan rumus Product Moment dengan membandingkan koefisien korelasi (r) hasil perhitungan dengan tabel. Hasil pengujian validitas menunjukkan dari total 32 item pernyataan terdapat 29 item valid dan 3 item tidak valid. Setiap item pernyataan yang menunjukkan hasil tidak valid akan dihapus. Penghapusan dilakukan karena setiap indikator variabel memiliki 2 item pernyataan sehingga jika salah satu tidak valid masih bisa menggunakan yang lainnya dan tidak perlu membuat pernyataan baru untuk angket. Maka diperoleh jumlah total item pada angket adalah 29 pernyataan. Sedangkan uji reliabilitas menggunakan nilai Alpha Cronbach sebagai penentuan reliabel atau tidaknya suatu instrumen. Hasil pengujian reliabilitas menunjukkan setiap variabel penelitian memiliki nilai Alpha lebih dari 0,06 sehingga dapat dikatakan bahwa instrumen penelitian reliabel.

Data penelitian yang telah terkumpul diolah dan dianalisis menggunakan bantuan Microsoft office excel dan aplikasi SPSS (Statistical Package for the Social Science). Teknik analisis data yang digunakan adalah deskriptif dan inferensial. Analisis deskriptif dipakai untuk menyajikan data penelitian menjadi bentuk angka-angka yang bermakna ke dalam diagram atau tabel. Teknik analisis ini menggunakan rumus persentase untuk memberikan gambaran yang lebih ringkas mengenai distribusi frekuensi dan kategori skor variabel penelitian. Sedangkan analisis inferensial dipakai untuk menyajikan data sampel yang hasilnya diberlakukan untuk populasi dan berkaitan dengan pengambilan suatu simpulan dari data yang telah diolah. Teknik analisis ini meliputi uji asumsi klasik terdiri atas uji normalitas, multikolinearitas dan heteroskedastisitas serta uji hipotesis menggunakan regresi linier berganda.

Uji asumsi klasik dilakukan sebagai prasyarat untuk uji hipotesis menggunakan regresi linier berganda. Hasil uji normalitas dengan Kolmogorov Smirnov menunjukkan nilai signifikansi sebesar 0,980 lebih besar dari alpha 0,05 sehingga dapat dikatakan bahwa data penelitian berdistribusi normal (asumsi normalitas terpenuhi). Hasil uji multikolinieritas memperlihatkan setiap variabel bebas memiliki nilai tolerance lebih besar dari 0,10 dan nilai VIF (Variance Inflation Factor) kurang dari 10,0 sehingga dapat dikatakan bahwa tidak ada korelasi kuat antara variabel bebas, maka analisis regresi berganda dapat dilanjutkan. Hasil uji heteroskedastisitas dengan uji glejser menunjukkan setiap variabel memiliki nilai signifikansi lebih besar dari nilai alpha 0,05 sehingga dapat dikatakan bahwa tidak terjadi gejala heteroskedastisitas pada model regresi.

Uji hipotesis dilakukan dengan menggunakan regresi linier berganda untuk mengetahui ada tidaknya pengaruh antara faktor-faktor terhadap hasil belajar peserta pelatihan secara parsial maupun simultan. Kriteria pengambilan keputusan adalah $\alpha=0,05$ atau tingkat kepercayaan 95\% serta Uji-t dengan (df) $=\mathrm{n}-\mathrm{k}-1=60$ diperoleh $\mathrm{t}_{\text {tabel }}=2,00030$ dan uji statistik $\mathrm{F}$ dengan $(\mathrm{df})=(\mathrm{k}: \mathrm{n}-\mathrm{k})=(8: 61)$, diperoleh $\mathrm{F}_{\text {tabel }}=2,09$.

\section{Hasil dan Pembahasan}

\subsection{Hasil}

UPT BLK Singosari Malang adalah lembaga penyelenggara pelatihan berbasis kompetensi dibawah naungan Dinas Tenaga Kerja dan Transmigrasi Provinsi Jawa Timur. 
Kapasitas latihnya mencapai 1920 orang atau 120 paket per tahun. Peminatnya pun tidak hanya berasal dari wilayah Malang tetapi mencakup seluruh Indonesia bahkan luar negeri.

Berdasarkan hasil analisis terhadap data yang telah terhimpun, diperoleh hasil analisis tentang faktor yang memengaruhi hasil belajar yaitu faktor internal (kesehatan, inteligensi, bakat, minat dan motivasi) dan faktor eksternal (keluarga, lembaga dan masyarakat) serta pengaruhnya pada hasil belajar peserta pelatihan.

Pada variabel $\mathrm{X}_{1}$ atau faktor internal kesehatan diperoleh hasil rata-rata jawaban keseluruhan responden yaitu mayoritas peserta memilih sangat setuju dengan persentase $68,6 \%$ dan berada pada kategori "sangat tinggi". Sementara itu, hasil uji-t secara parsial diperoleh $t_{\text {hitung }}=2,347>t_{\text {tabel }}=2,00030$ dan sign. 0,022 $<0,05$ berarti faktor internal kesehatan berpengaruh signifikan terhadap hasil belajar peserta pelatihan.

Pada variabel $\mathrm{X}_{2}$ atau faktor internal intelegensi diperoleh hasil rata-rata jawaban keseluruhan responden yaitu mayoritas peserta memilih setuju dengan persentase $60,5 \%$ dan berada pada kategori "tinggi". Sementara itu, hasil uji-t secara parsial diperoleh $t_{\text {hitung }}=1,969$ $<t_{\text {tabel }}=2,00030$ dan sign. 0,054 $>0,05$ berarti faktor internal intelegensi tidak berpengaruh signifikan terhadap hasil belajar peserta pelatihan.

Pada variabel $\mathrm{X}_{3}$ atau faktor internal bakat diperoleh hasil rata-rata jawaban keseluruhan responden yaitu mayoritas peserta memilih setuju dengan persentase $58,0 \%$ dan berada pada kategori "tinggi". Sementara itu, hasil uji-t secara parsial diperoleh $t_{\text {hitung }}=1,503$ $<t_{\text {tabel }}=2,00030$ dan sign. 0,138 $>0,05$ berarti faktor internal bakat tidak berpengaruh signifikan terhadap hasil belajar peserta pelatihan.

Pada variabel $\mathrm{X}_{4}$ atau faktor internal minat diperoleh hasil rata-rata jawaban keseluruhan responden yaitu mayoritas peserta memilih setuju dengan persentase $47,8 \%$ dan berada pada kategori "sangat tinggi". Sementara itu, hasil uji-t secara parsial diperoleh $t_{\text {hitung }}=$ $0,545<t_{\text {tabel }}=2,00030$ dan sign. 0,588 $>0,05$ berarti faktor internal minat tidak berpengaruh signifikan terhadap hasil belajar peserta pelatihan.

Pada variabel $\mathrm{X}_{5}$ atau faktor internal motivasi diperoleh hasil rata-rata jawaban keseluruhan responden yaitu mayoritas peserta memilih sangat setuju dengan persentase $47,3 \%$ dan berada pada kategori "sangat tinggi". Sementara itu, hasil uji-t secara parsial diperoleh $t_{\text {hitung }}=2,523>t_{\text {tabel }}=2,00030$ dan sign. $0,014<0,05$ berarti faktor internal motivasi berpengaruh signifikan terhadap hasil belajar peserta pelatihan.

Pada variabel $\mathrm{X}_{6}$ atau faktor eksternal keluarga diperoleh hasil rata-rata jawaban keseluruhan responden yaitu mayoritas peserta memilih sangat setuju dengan persentase $46,4 \%$ dan berada pada kategori "sangat tinggi". Sementara itu, hasil uji-t secara parsial diperoleh $t_{\text {hitung }}=2,018>t_{\text {tabel }}=2,00030$ dan sign. $0,048<0,05$ berarti faktor eksternal keluarga berpengaruh signifikan terhadap hasil belajar peserta pelatihan.

Pada variabel $\mathrm{X}_{7}$ atau faktor eksternal lembaga diperoleh hasil rata-rata jawaban keseluruhan responden yaitu mayoritas peserta memilih sangat setuju dengan persentase $45,3 \%$ dan berada pada kategori "sangat tinggi". Sementara itu, hasil uji-t secara parsial diperoleh $t_{\text {hitung }}=0,207<t_{\text {tabel }}=2,00030$ dan sign. 0,837 $>0,05$ berarti faktor eksternal lembaga tidak berpengaruh signifikan terhadap hasil belajar peserta pelatihan. 
Pada variabel $\mathrm{X}_{8}$ atau faktor eksternal masyarakat diperoleh hasil rata-rata jawaban keseluruhan responden yaitu mayoritas peserta memilih setuju dengan persentase 49,3\% dan berada pada kategori "tinggi". Sementara itu, hasil uji-t secara parsial diperoleh $t_{\text {hitung }}=3,615$ $>t_{\text {tabel }}=2,00030$ dan sign. 0,001 $<0,05$ berarti faktor eksternal masyarakat berpengaruh signifikan terhadap hasil belajar peserta pelatihan.

Hasil uji statistik F secara simultan diperoleh $F_{\text {hitung }}=4,324>F_{\text {tabel }}=2,09$ dan sign. 0,000 $<0,05$ berarti faktor kesehatan, inteligensi, bakat, minat, motivasi, keluarga, lembaga dan masyarakat secara bersama berpengaruh signifikan terhadap hasil belajar peserta pelatihan. Selanjutnya, nilai koefisien determinasi $\left(\mathrm{R}^{2}\right)$ sebesar 0,367 mempunyai makna faktor-faktor tersebut memengaruhi hasil belajar sebesar $36,7 \%$ dan sisanya dipengaruhi oleh faktor lain yang tidak diteliti.

Sementara itu, hasil belajar peserta pelatihan menunjukkan hasil yang bervariasi dengan nilai terendah 81,04 dan tertinggi 89,09. Mayoritas peserta peserta mendapat predikat nilai "baik sekali" artinya tingkat pencapaian hasil belajar peserta pelatihan di UPT BLK Singosari Malang adalah tinggi atau dengan kata lain kompeten pada bidang kejuruan pelatihannya.

\subsection{Pembahasan}

Penelitian mengenai faktor-faktor yang memengaruhi hasil belajar peserta pelatihan dilaksanakan di UPT BLK Singosari Malang yaitu lembaga pemerintah penyelenggara pelatihan yang berfokus pada kompetensi khususnya bidang industri. Pelatihan berbasis kompetensi menekankan pada pengembangan perilaku individu sesuai dengan standar kerja yang telah ditetapkan (Rusmulyani, 2021). Pelatihan jenis ini lebih banyak menerapkan pola praktek daripada teori dan menjadikan peserta didik mahir pada bidang yang dipilihnya. Adapun responden penelitian ini adalah sejumlah 69 peserta pelatihan program pemerintah tahun 2021.Berdasarkan data yang telah dianalisis diperoleh informasi mengenai hasil belajar peserta pelatihan berbasis kompetensi di UPT BLK Singosari Malang dan faktor-faktor yang memengaruhinya.

Belajar adalah usaha individu untuk mengembangkan diri melalui interaksi dan pengalaman. Individu dapat dikatakan sudah belajar apabila menunjukkan perubahan pola perilaku berupa pengetahuan, keterampilan dan sikap yang meningkat atau lebih baik. Perubahan yang timbul dari kegiatan belajar disebut sebagai hasil belajar. Hasil belajar peserta pelatihan merujuk pada penguasaan terhadap bahan ajar yang diberikan kepada mereka. Hasil belajar masing-masing peserta pelatihan tidak sama dan dipengaruhi oleh faktor tertentu seperti kesehatan, inteligensi, bakat, minat, motivasi, keluarga, lembaga dan masyarakat.

Kesehatan memegang peran penting bagi manusia, tanpa kesehatan individu sulit melakukan aktivitas termasuk ketika belajar. Sehat berarti tubuh dalam kondisi baik dan terbebas dari penyakit. Mayoritas peserta pelatihan pada variabel kesehatan menjawab sangat setuju dengan persentase $68,6 \%$ dan berada pada kategori sangat tinggi. Hal ini menunjukkan bahwa kesehatan peserta pada dasarnya telah sesuai dengan indikator instrumen, yaitu peserta pelatihan memiliki fisik yang sempurna dan kondisi kesehatan yang baik. Adanya indikator tersebut memperlihatkan kesehatan berpengaruh signifikan terhadap hasil belajar peserta pelatihan di UPT BLK Singosari dengan signifikansi sebesar 0,022. Peserta pelatihan dengan kesehatan yang baik lebih mudah mengikuti kegiatan belajar daripada peserta yang memiliki hambatan. Permatasari, dkk (2019) mengungkapkan kesehatan dan cacat tubuh 
merupakan faktor fisiologis yang berpengaruh terhadap keberhasilan belajar. Oleh Karena itu, peserta pelatihan harus selalu menjaga kesehatannya agar dapat mengikuti serangkaian kegiatan pelatihan dengan baik sehingga diperoleh pula hasil yang maksimal. Usaha menjaga kesehatan dapat dilakukan dengan cara konsumsi yang bergizi, istirahat cukup dan olahraga teratur. Lembaga pelatihan atau dalam hal ini UPT BLK Singosari juga perlu memperhatikan kesehatan peserta didiknya seperti, mengatur jadwal pelatihan dan pengadaan fasilitas kesehatan apabila diperlukan.

Inteligensi merujuk pada kapasitas individu untuk menerima berbagai keahlian dan menyelesaikan persoalan. Meskipun bukanlah satu-satunya penentu keberhasilan belajar, inteligensi dapat digunakan sebagai pertimbangan untuk mengukur hasil belajar. Mayoritas peserta pelatihan pada variabel intelegensi memilih setuju dengan persentase $60,5 \%$ dan berada pada kategori tinggi. Hal ini menunjukkan bahwa intelegensi peserta pada dasarnya telah sesuai dengan indikator instrumen, yaitu peserta pelatihan memiliki pengetahuan awal mengenai kejuruan yang diikuti dan menguasai materi pelatihan. Namun, indikator tersebut memperlihatkan inteligensi tidak berpengaruh signifikan terhadap hasil belajar peserta pelatihan di UPT BLK Singosari dengan signifikansi sebesar 0,054. Peserta pelatihan yang memiliki intelegensi tinggi berpeluang untuk memperoleh hasil yang lebih baik daripada peserta pelatihan dengan intelegensi rendah. Akan tetapi intelegensi tinggi belum tentu menjamin hasil yang lebih baik. Peserta pelatihan dengan inteligensi normal dapat memperoleh hasil maksimal apabila bersedia mengupayakan belajar dengan rajin dan faktor lain yang memengaruhi belajarnya cenderung ke arah positif. Menurut Diana dan Paidi (2019) pernyataan tentang tingkat kecerdasan tinggi akan membuat seseorang berhasil dalam belajar dan akhirnya sukses dalam kehidupan nyata adalah tidak selalu benar. Peserta pelatihan yang telah memiliki pengetahuan awal tentang bidang kejuruan yang diikuti akan lebih mudah dan cepat memahami materi terkait bidang tersebut daripada peserta yang awam. Apabila bekal pengetahuan tersebut dimanfaatkan dengan maksimal, peserta tentu akan mendapatkan hasil yang memuaskan. Sebaliknya, apabila peserta merasa pengetahuannya lebih baik dan lebih banyak mungkin saja ia merasa paling pintar dan meremehkan. Belajar tidak lagi dianggap penting karena memandang orang lain tidak akan mampu menandingi. Jika hal tersebut terjadi maka hasil belajar tidak akan menjadi lebih baik malah dapat mengakibatkan penurunan. Lebih lanjut, intelegensi peserta pelatihan pada penelitian ini terbatas pada penjelasan instrumen. Tes intelegensi dapat dilakukan guna mengetahui tingkat kecerdasan secara pasti.

Bakat adalah kemampuan individu untuk melakukan suatu aktivitas. Umumnya, bakat lebih menonjol daripada kemampuan yang lain. Peserta pelatihan yang memiliki bakat pada bidang kejuruan pelatihan yang diikuti akan lebih mudah dalam menyerap pengetahuan dan keterampilan daripada peserta lain yang kurang atau tidak memiliki bakat pada bidang itu. Mayoritas peserta pelatihan pada variabel bakat menjawab setuju dengan persentase $58,0 \%$ dan berada pada kategori tinggi. Hal ini menunjukkan bahwa bakat peserta pada dasarnya telah sesuai dengan indikator instrumen, yaitu peserta pelatihan memiliki bakat bawaan dan tidak mengalami kesulitan yang berarti. Namun, indikator tersebut memperlihatkan bakat tidak berpengaruh signifikan terhadap hasil belajar peserta pelatihan di UPT BLK Singosari Malang dengan nilai signifikansi sebesar 0,138. Bakat merupakan potensi bawaan. Peserta pelatihan yang berbakat berarti ia mampu untuk belajar dalam waktu singkat daripada peserta yang lain namun justru menunjukkan hasil lebih baik. Bakat yang dimiliki oleh peserta pelatihan dapat berkontribusi pada hasil belajarnya apabila dimanfaatkan dengan baik. Akan tetapi, hal yang harus dihindari adalah jangan sampai peserta merasa dirinya selalu bisa. 
Apabila hak tersebut terjadi maka mungkin saja ia tidak akan mengupayakan belajar dengan baik sehingga berdampak pada hasil yang akan diperoleh. Bakat adalah sesuatu yang senantiasa harus dilatih dan dikembangkan. Peserta yang kurang berbakat pada bidang kejuruan memungkinkan untuk memperoleh hasil yang lebih baik apabila ia bersungguhsungguh dalam belajar. Yohana, dkk (2020) mengungkapkan bahwa membimbing dan mengarahkan proses belajar sesuai dengan bakat dapat menghasilkan peningkatan kompetensi dan memperluas masa depan. Disinilah instruktur berperan untuk selalu membina peserta didiknya. Tes bakat juga dapat dilakukan untuk mengetahui potensi peserta pelatihan sehingga bisa diarahkan dan direkomendasikan hal yang berkaitan dengan bakatnya.

Minat adalah perasaan tertarik dan rasa ingin besar yang dimiliki oleh individu. Minat diekspresikan melalui ungkapan atau partisipasi dalam suatu kegiatan. Peserta pelatihan yang memiliki minat besar akan merasa suka, senang, tekun dan tidak mudah menyerah, sebaliknya peserta dengan minat rendah cenderung malas dan menghindar. Mayoritas peserta pelatihan pada variabel minat menjawab setuju dengan persentase $47,8 \%$ dan berada pada kategori sangat tinggi. Hal ini menunjukkan bahwa minat peserta pada dasarnya telah sesuai dengan indikator instrumen, yaitu peserta pelatihan memiliki keinginan yang besar dan merasa antusias terhadap kegiatan pelatihan. Namun, indikator tersebut memperlihatkan minat tidak berpengaruh signifikan terhadap hasil belajar peserta pelatihan di UPT BLK Singosari Malang dengan nilai signifikansi sebesar 0,588. Minat menjadikan peserta pelatihan memusatkan perhatiannya selama proses pembelajaran berlangsung. Apabila materi yang diberikan sesuai dengan minat maka akan mendorong peserta pelatihan untuk belajar dengan baik, sebaliknya materi yang tidak sesuai dengan minat dapat mengakibatkan mereka enggan untuk belajar karena tidak terdapat daya tarik baginya. Peserta pelatihan yang menaruh minat besar berpeluang untuk memperoleh hasil lebih baik, namun jika pelatihan yang diikuti ternyata kurang atau tidak sesuai dengan apa yang diekspektasikan dapat menyebabkan hasil belajar menjadi kurang optimal. Pada penyelenggaraan pelatihan di UPT BLK Singosari Malang peserta pelatihan tidak hanya diajarkan materi mengenai bidang kejuruan yang diikutinya, tetapi juga soft skill seperti budaya kerja dan kewirausahaan serta FMD atau fisik, mental dan disiplin. Setyawati (2019) mengungkapkan bahwa minat tidak sepenuhnya memengaruhi hasil belajar namun perubahan pada minat dapat berpengaruh pada tinggi rendahnya capaian hasil belajar. Disinilah instruktur pelatihan harus mampu membangkitkan minat peserta didik untuk senantiasa mempelajari materi yang terkandung dalam bidang kejuruannya. Upaya yang dapat dilakukan adalah dengan menggunakan metode belajar yang menarik serta menunjukkan banyak hal yang terkait dengan cita-cita dan kehidupan.

Motivasi merupakan dorongan untuk melakukan suatu aktivitas secara terarah dan berkaitan dengan usaha mencapai tujuan. Peserta pelatihan yang memiliki motivasi besar akan terdorong untuk belajar sebaik mungkin hingga berhasil meraih tujuannya. Mayoritas peserta pelatihan pada variabel motivasi menjawab sangat setuju dengan persentase $47,3 \%$ dan berada pada kategori sangat tinggi. Hal ini menunjukkan bahwa motivasi peserta pada dasarnya telah sesuai dengan indikator instrumen, yaitu peserta pelatihan memiliki keinginan untuk berkarier dan mendapatkan pengakuan mengenai bidang kejuruan pelatihan yang diikuti. Adanya indikator tersebut memperlihatkan motivasi berpengaruh signifikan terhadap hasil belajar peserta pelatihan di UPT BLK Singosari Malang dengan signifikansi sebesar 0,014. Motivasi turut berpengaruh pada aktivitas belajar seseorang. Triarisanti dan Purnawarnam (2019) mengungkapkan peserta didik yang memiliki motivasi tinggi cenderung mendapatkan hasil akhir yang lebih baik daripada peserta didik dengan motivasi rendah. Peserta pelatihan 
dengan motivasi tinggi akan berusaha semaksimal mungkin, bersungguh-sungguh dan pantang menyerah. Motivasi yang semakin tinggi akan membawa hasil belajar yang lebih baik sebab peserta pelatihan memiliki dorongan yang kuat untuk mencapai sesuatu yang menjadi tujuannya. Motivasi tersebut berupa keinginan untuk berkarir pada bidang kejuruan, mudah dalam mencari kerja dan mendapat pengakuan terhadap kompetensi yang dimilikinya.

Keluarga adalah lembaga pendidikan anak yang pertama. Pendidikan dalam keluarga membangun kepribadian anak dan memengaruhi pilihan untuk bertindak. Mayoritas peserta pelatihan pada variabel keluarga menjawab sangat setuju dengan persentase $46,4 \%$ dan berada pada kategori sangat tinggi. Hal ini menunjukkan bahwa lingkungan keluarga peserta pada dasarnya telah sesuai dengan indikator instrumen, yaitu keluarga memberi dukungan dan suasana rumah nyaman untuk belajar. Adanya indikator tersebut memperlihatkan keluarga berpengaruh signifikan terhadap hasil belajar peserta pelatihan di UPT BLK Singosari Malang dengan signifikansi 0,048. Keluarga merupakan lingkungan tempat anak bertumbuh. Sebelum memasuki dunia persekolahan anak telah mendapatkan pendidikan di keluarga seperti agama, kasih sayang, sopan santun dan kebiasaan hidup lainnya. Anak melakukan interaksi untuk pertama kali dan menghabiskan sebagian besar waktunya dalam lingkungan keluarga, sehingga segala situasi yang terjadi didalam nya berpengaruh terhadap kehidupan anak, termasuk dalam aktivitas belajar. Kaukab (2016) mengungkapkan keluarga terutama orang tua adalah faktor penting yang turut berkontribusi pada perolehan hasil belajar anak. Keluarga yang peduli satu sama lain dan orang tua yang selalu memperhatikan pendidikan anak akan menjadikan kegiatan belajar lebih terarah dan optimal. Selain itu, menciptakan suasana rumah yang nyaman dan damai perlu dilakukan agar anak dapat belajar sebaik mungkin dan fokus. Peserta pelatihan di UPT BLK Singosari Malang tinggal dalam keluarga yang mendukung belajarnya, yaitu orang tua memenuhi semua kebutuhan pelatihan, keluarga memberikan semangat dan dukungan, serta kondisi rumah nyaman untuk belajar. Semakin baik lingkungan keluarga mendukung kegiatan belajar maka hasil belajar yang didapatkan juga akan lebih baik.

Lembaga adalah tempat berlangsung nya kegiatan pelatihan. Segenap komponen yang ada dalam lembaga turut berkontribusi dan berpengaruh pada capaian hasil belajar. Mayoritas peserta pelatihan pada variabel lembaga menjawab sangat setuju dengan persentase $45,3 \%$ dan berada pada kategori sangat tinggi. Hal ini menunjukkan bahwa lembaga tempat peserta mengikuti kegiatan pelatihan atau dalam hal ini adalah UPT BLK Singosari Malang pada dasarnya telah sesuai dengan indikator dalam instrumen, yaitu fasilitas yang disediakan menunjang kegiatan belajar dan lingkungan sosial yang mendukung (Instruktur dan teman sekelas). Namun, indikator tersebut memperlihatkan lembaga tidak berpengaruh signifikan pada hasil belajar peserta pelatihan di UPT BLK Singosari Malang dengan signifikansi 0,837. Lembaga berperan dalam memengaruhi hasil belajar, sebab peserta didik melakukan aktivitas belajarnya di lingkungan lembaga tersebut. Berbagai komponen baik fasilitas maupun orangorang yang terlibat pada kegiatan belajar turut berkontribusi dalam menentukan pencapaian hasil belajar peserta pelatihan. Semakin lingkungan lembaga mendukung maka hasil yang dicapai juga akan lebih baik, sebaliknya lembaga yang kurang mendukung dapat mengakibatkan pencapaian hasil belajar kurang maksimal. Ogundokum (2011) mengungkapkan bahwa interaksi berbagai komponen lembaga dapat menciptakan dukungan yang memungkinkan bagi semua anggota komunitas lembaga melakukan kegiatan belajar dan mengajar pada tingkatan lebih optimal. Penanganan lingkungan lembaga seperti meningkatkan kesejahteraan pendidik dan tenaga pelatihan serta mengembangkan sarana dan 
prasarana dapat dilakukan dalam upaya meningkatkan hasil belajar peserta pelatihan. Sementara itu, belajar adalah usaha merubah perilaku peserta didik dengan banyak faktor yang memengaruhi. Apabila lembaga telah memberikan dukungan yang baik tetapi faktor lain yang memengaruhi tidak maka hasil yang dicapai oleh peserta didik juga tidak menjadi maksimal.

Masyarakat adalah orang-orang di lingkungan tempat tinggal peserta pelatihan. Lingkungan masyarakat melibatkan situasi dan interaksi antar individu didalamnya. Mayoritas peserta pelatihan pada variabel masyarakat menjawab setuju dengan persentase $49,3 \%$ dan berada pada kategori tinggi. Hal ini menunjukkan lingkungan masyarakat sekitar tempat tinggal peserta pada dasarnya telah sesuai dengan indikator dalam instrumen, yaitu kondisi lingkungan mendorong untuk belajar dan teman bergaul memberikan bantuan dalam belajar. Adanya indikator tersebut memperlihatkan bahwa masyarakat berpengaruh signifikan terhadap hasil belajar peserta pelatihan di UPT BLK Singosari Malang dengan signifikansi 0,001. Masyarakat turut memiliki peranan dalam memengaruhi aktivitas belajar individu, sebab individu cenderung akan mengikuti kebiasaan dan berperilaku sama dengan orangorang di sekitarnya. Peserta pelatihan yang tinggal dalam lingkungan masyarakat yang mendukung belajarnya berpeluang untuk mendapat hasil lebih baik daripada peserta yang tinggal dalam masyarakat yang kurang atau tidak mendukung. Wijaya dan Bukhori (2017) mengungkapkan bahwa faktor masyarakat adalah lingkungan tempat tinggal, gaya hidup, dan pergaulan yang berpengaruh terhadap hasil belajar. Apabila masyarakat terdiri dari orangorang yang berperilaku baik dan berpendidikan tentu akan memberi pengaruh positif, sebaliknya apabila masyarakat terdiri dari orang-orang berperilaku buruk dan kurang berpendidikan maka akan berpengaruh negatif. Peserta pelatihan di UPT BLK Singosari Malang tinggal dalam masyarakat yang mendukung aktivitas belajar. Dukungan tersebut berupa bentuk kehidupan yang mendorong untuk belajar, lingkungan tempat tinggal memiliki fasilitas belajar serta teman bermain yang memberi masukan dan membantu mengatasi kesulitan. Oleh karena itu, orang tua harus selalu membina dan mengawasi anak agar bergaul dengan orangorang baik yang dapat menunjang dan mendukung belajar sehingga diperoleh hasil yang maksimal.

Uji-t parsial yang memperlihatkan hasil tidak signifikan bukan berarti faktor tersebut tidak berpengaruh pada hasil belajar tetapi data sampel gagal membuktikan hubungan tersebut atau dengan kata lain faktor itu tidak memiliki pengaruh terhadap hasil belajar yang didapatkan oleh peserta pelatihan berbasis kompetensi di UPT BLK Singosari Malang. Hasil tidak signifikan dapat dipengaruhi oleh keterbatasan dalam penelitian seperti pemilihan sampel yang kurang sesuai, jenis data yang dipakai atau instrumen penelitian yang digunakan.

Belajar merupakan sebuah proses dengan berbagai faktor yang memengaruhi. Hasil uji statistik F menunjukkan bahwa faktor-faktor (kesehatan, inteligensi, bakat, minat, motivasi, keluarga, lembaga dan masyarakat) berpengaruh simultan terhadap hasil belajar peserta pelatihan di UPT BLK Singosari Malang dengan signifikansi 0,000. Faktor internal merupakan kondisi dari dalam diri peserta pelatihan yang memiliki pengaruh terhadap kegiatan belajarnya. Kondisi tersebut berupa kesehatan yang baik, pengetahuan dasar mengenai bidang kejuruan pelatihan, bakat yang sesuai dan memadai, rasa tertarik dan perhatian pada pelatihan, serta tujuan yang mendorongnya. Sedangkan faktor eksternal merupakan lingkungan sekitar peserta yang terdiri dari keluarga, lembaga dan masyarakat yang mendukung kegiatan belajar. Faktor-faktor tersebut saling terkait satu sama lain. Oleh 
karenanya, dalam penyelenggaraan kegiatan pelatihan faktor yang berkontribusi pada pencapaian hasil belajar harus menjadi perhatian dan dikelola sedemikian rupa sehingga membuahkan hasil yang baik. Selanjutnya, nilai koefisien determinasi $\left(\mathrm{R}^{2}\right)$ sebesar 0,367 mempunyai makna faktor tersebut memengaruhi hasil belajar sebesar $36,7 \%$ dan lainya dipengaruhi oleh faktor lain diluar penelitian. Peserta pelatihan akan memperoleh hasil yang baik apabila ia mau mengupayakan belajar dengan giat dan rajin serta faktor yang memengaruhi belajarnya menuju ke arah positif.

Hasil belajar peserta pelatihan menunjukkan penguasaan peserta terhadap bidang kejuruan yang diikuti. Muryanto (2019) mengungkapkan bahwa hasil belajar menunjukkan kemampuan yang diperoleh peserta didik sesuai tujuan yang ditetapkan. Hasil belajar bisa berupa angka atau huruf dan dapat diketahui setelah kegiatan belajar selesai. Hasil belajar peserta pelatihan di UPT BLK Singosari memperlihatkan nilai yang bervariasi dengan skor terendah 81,04 dan tertinggi 89,09. Nilai ini diperoleh dari penilaian masing-masing instruktur kejuruan kepada peserta pelatihan yang mencakup nilai akademis dan sikap. Nilai akademis merupakan penilaian mengenai penguasaan peserta didik terhadap materi pelatihan baik dari segi teori maupun praktek, sedangkan nilai sikap merujuk pada aspek kehadiran, disiplin, prakarsa, kerjasama dan penerapan K3. Bobot penilaiannya adalah $60 \%$ nilai akademis dan $40 \%$ nilai sikap yang diolah sedemikian rupa hingga diperoleh nilai akhir yang memperlihatkan hasil belajar peserta pelatihan. Mayoritas peserta memperoleh predikat nilai baik sekali berarti hasil belajar peserta pelatihan pada dasarnya sudah baik atau dengan kata lain kompeten pada bidang kejuruan pelatihan. Lebih lanjut, Rohmad (2020) mengungkapkan bahwa keberhasilan pelatihan berkaitan dengan bertambahnya kemampuan peserta didik dan merupakan indikator efektivitas pelatihan.

\section{Simpulan}

Hasil belajar peserta pelatihan di UPT BLK Singosari Malang terdiri atas nilai akademis dan nilai sikap yang diberikan oleh instruktur kejuruan kepada peserta pelatihan. Hasil belajar peserta menunjukkan hasil yang bervariasi dengan nilai terendah 81,04 dan tertinggi 89,09. Sementara itu, mayoritas peserta memperoleh predikat nilai baik sekali artinya tingkat pencapaian hasil belajar peserta pelatihan adalah tinggi atau dengan kata lain peserta kompeten pada bidang kejuruan pelatihannya.

Perbedaan hasil belajar yang didapat peserta pelatihan dipengaruhi oleh berbagai faktor, baik internal dan eksternal. Faktor internal adalah kondisi dalam diri peserta pelatihan meliputi kesehatan, inteligensi, bakat, minat dan motivasi. Faktor eksternal adalah lingkungan sekitar peserta pelatihan meliputi keluarga, lembaga dan masyarakat. Peserta pelatihan dengan nilai tinggi berarti faktor-faktor yang mempengaruhi belajarnya menuju ke arah positif, sedangkan peserta dengan nilai rendah dapat disebabkan faktor yang mempengaruhi belajarnya cenderung ke arah negatif atau berkontribusi kecil.

Hasil analisis regresi linier berganda menunjukkan faktor kesehatan, motivasi, keluarga dan masyarakat secara parsial berpengaruh signifikan. Sedangkan faktor intelegensi, bakat, minat dan lembaga secara parsial tidak berpengaruh signifikan pada hasil belajar. Hasil uji-t secara parsial yang memperlihatkan hasil tidak signifikan bukan berarti faktor tersebut tidak mempengaruhi hasil belajar tetapi data sampel gagal membuktikan hubungan antara keduanya atau dengan kata lain faktor tersebut tidak memiliki pengaruh pada hasil belajar peserta pelatihan di UPT BLK Singosari Malang. 
Sementara itu, hasil uji statistik F simultan menunjukkan faktor-faktor secara bersama berpengaruh terhadap hasil belajar peserta pelatihan dengan kontribusi $36,7 \%$.

\section{Daftar Rujukan}

Diana, D. M., \& Paidi. (2019). The Effect of Multiple Intelligence-based Learning Strategies, Mathematical Logic and Naturalist toward Cognitive Learning Outcomes and Biological Retention of Students X on Environmental Pollution Material. Journal of Physics: Conference Series , 1-8.

Hani, A. (2020). Efektivitas Pelatihan Berbasis Kompetensi terhadap Peningkatan Kinerja. Jurnal AgriWidya , 1-9.

Ilyas, M., Farid, M., \& Akbar, M. (2017). Efektivitas Penyebaran Informasi Rekrutmen Peserta Didik Pelatihan Berbasis Kompetensi pada Balai Latihan Kerja Kab. Majene. Jurnal Komunikasi KAREBA , 162-173.

Kaukab, S. R. (2016). The Impact of Parent/Family Involvement on Student's Learning Outcomes. International Journal of Research Granthaalayah , 72-81.

Lodjo, F. S. (2013). Pengaruh Pelatihan, Pemberdayaan dan Efikasi Diri terhadap Kepuasan Kerja. Jurnal EMBA , 747-755.

Muryanto, U. (2019). Hasil Belajar Peserta Diklat Teknis Substantif Media Pembelajaran Berbasis Multimedia. Jurnal Diklat Keagamaan , 50-57.

Ogundokun. (2011). Learning Style, School Environtment and Test Anxiety as Correlates of Learning Outcomes Among Secondary School Students. An International Journal of Psychology in Africa , 321-336.

Permatasari, B. D., Gunarhadi, \& Riyadi. (2019). The Influence of Problem Based Learning Towards Social Science Learning Outcomes Viewed from Learning Interest. International Journal of Evaluation and Research in Education (IJERE) , 39-46.

Rohmad, A. N. (2020). Analisis Faktor-Faktor yang Mempengaruhi Keberhasilan Peserta Pelatihan. Naskah Publikasi Ilmiah Universitas Muhammadiyah Surakarta , 1-13.

Rusmulyani. (2021). Technical Vocational Education Training (TVET) Innovation dengan Model Pelatihan Berbasis Kompetensi dalam Pengembangan Soft Skill Sumber Daya Manusia. Jurnal Inovasi Penelitian , 1495-1506.

Saputri, Y., Purwito, L., \& Widianto, E. (2019). Pengaruh Kompetensi Fasilitator dan Hasil Belajar Peserta Pelatihan Keluarga Sehat. Jurnal Pendidikan Nonformal , 22-36.

Septyana, H. (2013). Manajemen Pembelajaran Berbasis Kompetensi Pelatihan Menjahit di Lembaga Pelatihan Kerja Swasta (LPKS) Fortuna Dukuh Siberuk Desa Siberuk Kabupaten Batang. Journal of Non Formal Education dan Community Empowerment , 46-50.

Setyawati, A. (2019). Pengaruh Minat dan Percaya Diri terhadap Prestasi Belajar Peserta Pelatihan Dasar Fungsional Penyuluh Pertanian Terampil di Balai Besar Pelatihan Kesehatan Hewan (BBPKH) Cinagara. Jurnal AgroSainTa , 72-81.

Slameto. (2013). Belajar dan Faktor-Faktor yang Mempengaruhinya. Jakarta: PT. Rineka Cipta.

Syah, M. (2011). Psikologi Belajar. Jakarta: Rajawali Pers.

Triarisanti, R., \& Purnawarman, P. (2019). The Influence of Interest and Motivation on College Students's Language and Art Appreciation Learning Outcomes. International Journal of Education , 130-135.

Widianto, E. (2018). Pola Penyelenggaraan Pendidikan dan Pelatihan di Balai Diklat Keuangan Kota Malang. Ilmu Pendidikan: Jurnal Kajian Teori dan Pratik Kependidikan , 40-49.

Wijaya, O. P., \& Bukhori, I. (2017). Effect of Learning Motivation, Family Factor, School Factor, and Community Factor on Student Learning Outcomes on Productive Subjects. Jurnal Pendidikan Bisnis dan Manajemen , 192-202.

Yohana, C., Agung, I., Perdana, N. S., \& Silisabon, S. (2020). A Study of Factors Influencing the Development of Student Talent. International Journal of Education and Practice , 441-456. 